\title{
Free movement of people in the European Union and recognition of same-sex marriages on the example of Poland, Ireland and France
}

\author{
Karolina Bicz ${ }^{1}$ (D) \\ 1 Ph.D. student in law sciences at the University of Silesia, Katowice, POLAND. e-mail: karolinabicz1991@gmail.com
}

\begin{abstract}
The article presents the issue of the free movement of persons in the European Union in the field of same-sex marriage rights, taking into account comparative elements. The research presents provisions of the European Union, as well as internal regulations in force in France, Ireland and Poland. The article discusses the approach to the analysed issue at the level of EU regulations and internal regulations of the examined Member States. Moreover, the interaction between EU and national regulations is an important research point. Besides the article shows case variants concerning the recognition of same-sex relationships due to the legal and ideological conditions in the analysed countries Also, the article analyses the impact and importance of the Court of Justice of the European Union and the European Court of Human Rights for the studied topic. In addition, the study takes into consideration the impact of constitutional provisions on the legalization of homosexual couples in the analysed countries. The article is divided into parts covering the following issues: free movement of persons in the European Union, the right to family reunification of European Union citizens, relations between European Union law and the internal law of the Member States, recognition of same-sex marriages in France, Ireland and Poland, and summary. The opinions of A. Tryfonidou, H. Verschueren, P. Tulea and M. Bell were included in the study due to their importance to the research are.
\end{abstract}

Keywords: Free Movement of Persons in European Union, The Right to Family Reunification, The Rights of LGBTI People in The European Union.

* The author specializes in the topic of free movement of workers in the European Union 


\section{INTRODUCTION}

The free movement of people in the European Union (hereinafter referred to as the EU) constitutes the right of every EU citizen. This principle is related to the right of family reunification of migrants. In its activities, the European Union seeks to respect the right of every entity to create a family and takes steps to facilitate its exercise. However, it should be noted that although some issues are regulated at the EU level, the Union allows for diversity in the Member States. Due to the above facts, it is worth taking a closer look at the issue of the right of a mobile person to family reunification in the European Union from the perspective of homosexual marriage.

The problem of recognizing the homosexual couples constitutes the subject of analysis of many sciences, in particular social and humanities. However, presenting this issue in the field of legal sciences, explaining the relations between the regulations of $\mathrm{EU}$ and national law of the countries seems interesting. The EU and Court of Justice of the European Union (hereinafter the CJEU) do not take radical action and allows the member states to regulate this issue by national law.

The comparative analysis will be carried out on the basis of European Union regulations and internal regulations of the following Member States: Poland, Ireland and France. The discussed countries display differences in terms of culture, law and religion, therefore comparing the functioning of the principle of free movement of persons and the right to recognize the status of same-sex marriages in these countries seems interesting. The discussed countries were selected due to their diversity in regulating the analysed topic. All three countries belong to historically Catholic countries. Nevertheless, religious and ideological views have changed over the years, in particular in France and Ireland. The selected countries demonstrate all possible case solutions regarding the free movement of workers of gay couples. This issue has not been fully discussed in the doctrine, and the comparative element allows for deepening the issue with the national aspect of EU countries.

The aim of the article is not to answer the question whether member states should legalize homosexual relationships, but to present the existing case solutions concerning homosexual couples exercising the free movement of persons in the European Union in the discussed countries. The analyses consider the provisions of the Polish, Irish and French constitution which have a direct impact on the regulations concerning this issue in internal regulations.

The research was carried out based on the applicable provisions of the European Union, internal law in Poland, Ireland and France, the jurisprudence of the Court of Justice of the European Union and the views presented in the literature on the subject.

The article is divided into parts covering the following issues: free movement of persons in the European Union, the right to family reunification of European Union citizens, relations between European Union law and the internal law of the Member States, recognition of same-sex marriages in France, Ireland and Poland, and summary. The views of A. Tryfonidou, H. Verschueren, P. Tulea and M. Bell were considered in the study. Due to their important and groundbreaking views on the study research.

The work covers the following research areas: EU law, norms of Polish law, norms of Irish law, norms of French law, analysis of the position of international doctrine and jurisprudence of the CJEU. To conduct the research, the following methods were used: legal-comparative, formaldogmatic and empirical.

\section{FREE MOVEMENT OF PEOPLE IN THE EUROPEAN UNION}

The analysis should start with the explanation of the essence of the free movement of persons in the European Union, as the above law allows EU citizens to exercise their right to family reunification.

The free movement of persons is one of the most complex and problematic freedoms in the European Union's common market, both in the political and legal terms. Undoubtedly, the free movement of persons has political implications more than any other kind of freedom (Cuyvers, 2017: 354).

The right to free movement has evolved over the years initially it was available only to economically active people, but with time it was extended to all EU citizens. It was the introduction of the citizenship of the European Union into the Maastricht Treaty that initiated a change in this matter - it was then that the scope of the right to freedom of movement was extended (Treaty on European Union, 2012/C 326/01). Its foundation is the ability to move and reside freely within the territory of the European Union, regardless of the undertaken business activity, but subject to the limitations provided for by the EU regulations (Verschueren, 215: 1012).

The right to free movement of citizens is guaranteed in art. 45 of the EU Charter of Fundamental Rights and, above all, in art. 21 TFEU. According to CJEU direct effect of article 18(1) EC ( now article 21 TFEU), confirming that this right is conferred directly on every Union citizen (Baumbast, 2002, C-413/99, EU:C:2002:493, pt. 84). Moreover, CJEU emphasized that EU citizenship confers individual rights, such as the right to move around and remain in the host country's territory (Lassal, 2010, C-162/09, EU:C:2010:592, 
pt. 29). The right to free movement of citizens is guaranteed by the Treaty and should be interpreted broadly, respecting the principle of proportionality.

In the famous case of Grzelczyk, CJEU ruled that EU citizenship is to be the basic status of every EU citizen. In later years, the principle set out here has been repeated numerous times in the judgements of CJEU. Subsequently, this right was combined with the prohibition of discrimination based on origin (art. 18 of TFEU) with regard to exercising the right to move and reside in another Member State (Grzelczyk, 2001, C-184/99, EU:C:2001:458, pt. 31).

At the end of this fragment, it seems necessary to clarify the relationship between the primary EU law like Treaty on the Functioning of the European Union and jurisprudence of the Court of Justice of the European Union. According to G. A. Caldeira and J. L. Gibson, CJEU has an important influence on EU law and the laws of the Member States (Caldeira, Gibson, 1995: 356-358). The CJEU helps Member States to interpret EU law correctly and fills legal gaps in the absence of a standard definition in EU primary or secondary law. The impact of the CJEU jurisprudence on EU regulations is often discussed in the legal doctrine due to its importance for both EU law and the internal law of the Member States (Davies, Bogg, Costello, 2016: 134-136).

Undoubtedly, the activity of the CJEU for the development of such an important idea as EU citizenship and the rights associated with this privilege is indisputable.

\section{THE RIGHT TO FAMILY REUNIFICATION OF EUROPEAN UNION CITIZENS}

Marriage is a type of contract between two people that carries with it both obligations and rights, including the right to travel and move together. With few exceptions, a lawful marriage in one state is recognized in another. According to $\mathrm{K}$. Waaldijk, the law includes the principle of the free movement of marital status, which supports and coexists with the free movement of married persons (Waaldijk, 1996: 271-272).

Currently, the 2004/38/EC Directive under secondary law regulates the free movement of economically active and inactive EU citizens. Anyone with EU citizenship has the right to move to another country for 3 months without registering. This right also extends to third-country nationals who travel with the EU citizen (Guild, 2016: 231-249). The 2004 Directive regulates the right to family reunification of migrants. Article 2, point 2 of 2004/38 Directive defines a family member as:

“a) spouse; b) the partner with whom the Union citizen has contracted a registered partnership, under the legislation of the Member State concerned, if the legislation of the host Member State recognizes registered partnership as equivalent to marriage, and in accordance with the conditions laid down in the relevant legislation of the host Member State;

c) the direct descendants who are under the age of 21 or are dependents and those of the spouse or partner as defined in point b);

d) the direct dependent ascendants and those of the spouse or partner as defined in b);" (Directive 2004/38/EC, L 158/7).

The family members listed above are entitled to join an EU mobile citizen, even if they are from a third country. However, this only applies to the partner with whom the Union citizen has a lasting relationship which is duly certified. However, the status of lawfully contracted marriages between persons of the opposite sex is clear under EU law, as opposed to that of homosexual unions (Tryfonidou, 2015: 208 -211).

The 2004 Directive recognizes a migrant's spouse as a close family member of an EU citizen, hence such a person may exercise the right to family reunification (2004/38/EC Directive, L158/7). It might seem that, since in some Member States homosexual couples also have the possibility to marry, the said provision should be interpreted broadly and also cover same-sex marriages (Costello, 2009: 615-616). However, in practice, the directive did not define the spouse issue at EU level so as to ensure the unquestionable right to family reunification of samesex couples. In addition, practice shows that CJEU does not want to establish the EU definition of a spouse due to differences in regulations concerning this issue in the domestic law of the Member States. However, differences in the Member States can jeopardize the rights guaranteed in primary and secondary law. Therefore, although samesex spouses were not excluded from the scope of the 2004 Directive, it was not expressly stated that they fell within the scope of the term spouse. Consequently, it is not expressly stated whether the host State must automatically recognize same-sex marriages in another Member State and exercised the right to freedom of movement. For these reasons, some EU countries have the right to refuse to respect the rights of homosexual marriage to cross-border entities, which reduces its status to a registered partner or to non-recognition of the marriage in the host country. According to A. Tryfonidou, the failure of the European Union to explain that the status of same-sex marriages should be respected in all Member States implies a tacit acceptance that this issue is based on the legal principles of the host country. Nevertheless, it is worth looking at these relationships as part of further considerations (Tryfonidou, 2015: 210-212). 


\section{RELATIONS BETWEEN THE EUROPEAN UNION LAW AND THE DOMESTIC LAW OF THE MEMBER STATES}

The Court of Justice of the European Union has been called on several occasions to change its approach to the issue of marriage due to the social changes taking place in the EU. The key was the speech of Advocate General Tesauro, who stated that "the law must not cut itself off from society as it really is, and it must not neglect to conform to it as quickly as possible. Because doing so risks imposing outdated views and assuming a static role" (Advocate General Tesauro, 1995, C-13/94, EU:C:1995:444).

Later, Advocate General Geelhoed in his famous speech drew attention to the fact that the EU provisions on the migration law of EU citizens on family reunification should be updated due to the social and legal changes that have occurred since the adoption of the 1612/682 Regulation (this Act regulated these issues at that time), (Advocate General Geelhoed, 2001, C-413/99, EU:C:2001:385). Both spokesmen made it clear that the European Union should cope with constant social changes and adapt the existing legal provisions to the new social landscape.

When starting to consider the relationship between the EU regulations and the domestic law of the Member States, it is worth noting that already in $2002 \mathrm{M}$. Bell, in his publication, emphasized the need to regulate the issue of same-sex marriage at the EU level in order to prevent the emergence of barriers on the internal market. Moreover, the author indicated that it would be more advantageous for the EU to regulate some aspects rather than delegating the management to the CJEU. However, it was also pointed out that the EU seeks to respect internal rules and it may not be possible to achieve uniformity in this area (Bell, 2002: 353-355).

Although eighteen years have passed since the publication of the quoted publication, the issue raised in the quoted article is still valid. In line with the adopted EU tactic, each member state regulates the recognition of same-sex relationships and marriages within its own domestic law. In the European Union, all Western countries recognize samesex relationships, but there are still differences in their legal status from country to country. France and Ireland are among the countries that legally recognize the status of same-sex couples. However, still six counties from Eastern Europe do not provide legal recognition of same-sex unions, including Poland (Tryfonidou, 2019: 215-2016). Moreover, it should be noted that in Poland there is a constitutional ban on marriage by persons of the same sex (Constitution of the Republic of Poland, Journal of Laws of 1997 no. 78 item 483).
At this stage, it is worth mentioning the case of Coman, in which CJEU currently spoke about the recognition of gay marriage in the EU. The case concerned a homosexual couple - Mr. Coman, who had Romanian and American citizenship, and Mr. Hamilton, who had only American citizenship. The couple got married in 2010 in Belgium under the country's legislation, then contacted the Romanian Migration Officer to grant Mr. Hamilton the right of residence in Romania under EU law. The Romanian authorities refused because same-sex marriages are prohibited under the country's internal law and those contracted abroad are not recognized. The married couple complained of discrimination on the basis of sexual orientation, thus violating the EU's right to free movement within the EU. The internal court asked CJEU(Coman, 2018, C-673/16, EU:C:2018:385, pt. 34-56).

The Court of Justice of the European Union stated that "refusal by the authorities of a Member State to recognize solely for the purpose of granting a derived right of residence to a third-country national - a marriage entered into by him with a Union citizen of the same sex during their effective stay in another Member State, in accordance with the law of that Member State, laid down in art. 21 par. 1 TFEU. The consequence of such a refusal will be to deprive the Union citizen concerned of the possibility of returning to the Member State of which he or she is national, together with the spouse" (Ibidem, pt.40).

In addition, according to CJEU, a measure provided for by the internal rules of EU countries that infringe the freedom of movement may be justified if it does not conflict with the rights guaranteed by the Chart of Fundamental Rights, and it was therefore established that the status of the spouse and the right to respect for private and family life are protected under art. 7 of the EU Charter of Fundamental Rights (Ibidem, pt.47).

However, despite the above arguments, "several governments which have submitted observations to the Court have emphasized in this respect the fundamental nature of the institution of marriage and the will of some Member States to preserve the concept of this institution as a union of man and woman, protected in some Member States by constitutional norms" (Ibidem, pt. 42). Ultimately, the Court stated that it respected the national identities of the member states, inextricably linked with their basic political and constitutional structures, and held that member states remain free to decide whether or not to allow same-sex marriages. CJEU further stressed that the judgement did not require an EU country to provide for same-sex marriage in its national law (Ibidem, pt.42-51). At the end of the description of the judgement itself, it is worth noting that Poland supported the position of the Romanian government in this matter, while France and Ireland took a different position. Nevertheless, 
this decision had a significant impact on the current views and started a wave of scientific publications discussing this issue. First of all, in this judgement, CJEU departed from its earlier case law, according to which marriage was generally accepted as a union between two persons of the opposite sex. According to J. MacLennan and A. Ward, the Coman ruling will have a breakthrough impact on the rights of same-sex marriage in the European Union. Moreover, the impact of this ruling would have been greater if the decision was based more broadly on the Charter of Fundamental Rights ((MacLennan, Ward, 2020: 54-61). A. Tryfonidou is of the same opinion, according to which CJEU did not base its decision on human rights as a separate legal basis (Tryfonidou, 2019: 215).

When analysing the relationship between EU law and domestic law, the issue of the European Convention on Human Rights and jurisprudence of European Court of Human Rights cannot be excluded. The European Convention of Human Rights was created following the cruelty of the Second World War. The regulation on human rights in the EU is supplemented by the jurisprudence of the European Court of Human Rights (Hamilton, 2018: 1599).

The European Convention on Human Rights provides the primary source of international protection of same-sex couple. Under ECHR the Member States of the Council of Europe promise to secure fundamental civil and political rights, not only to their citizens but also to everyone within their jurisdiction. The ECHR allows the European Court of Human Rights to examine inter-State cases and individual complaints regarding violations of the ECHR. The European Court of Human Rights has the most significant and most considerable jurisprudence in addressing sexual orientation cases. It was the first international body which recognized sexual orientation criminal laws violate human rights (Juozulynas, Śmiszek, 2011: 17).

However, The European Convention on Human Rights does not include a specific sexual orientation non-discrimination clause. This lack of direct protection for same-sex couples could be ameliorated if more European Union countries signed the freestanding Protocol 12 (Convention for the Protection of Human Rights and Fundamental Freedoms, Rome, 4.XI.1950). However, not every government has decided to ratify Protocol 12. All analysed countries signed the Convention for the Protection of Human Rights and Fundamental Freedoms, but France, Ireland and Poland did not ratify the protocol 12 .

Therefore, the recognition of homosexual relationships and the accompanying jurisprudence of the European Court of Human Rights is problematic in the relation between the EU law and the domestic law of the Member States. Unlike the U.S. Supreme Court, the European Court is very much restricted by the competing interests of its member states. "Under the European Convention, "primary responsibility" is given to member states to secure human rights. The role of the European Court is, in fact, secondary. Although the European Court's judgments are binding in international law, there is no enforcement mechanism, and the European Court depends on member states to change their legislation and practices"(Hamilton, 2018: 1584).

As indicated above, the relationship between EU law and domestic law in the matter of recognizing homosexual couple is complex. Both the European Court of Human Rights and the Court of Justice of the European Union, in particular the CJEU, maintain the technical nature of their judgments. The technical nature of the jurisdictions avoids political problems by achieving a generally acceptable line of rationalizing (Jacobi, 2011: 666).

The author of the dissertation agrees with the above opinion of $\mathrm{H}$. A. Jacobi because the technical nature of the CJEU jurisprudence is noticeable primarily in problematic issues, such as the right to family reunification of homosexual couples where the CJEU does not interpret this issue and maintains the continuity of its jurisprudence.

Continuing the deliberations on the dependence of $\mathrm{EU}$ regulations and internal law norms, it should be emphasized that, in accordance with the applicable assumptions, permitted by the European Union, a Member State that does not recognize same-sex relationships in its territory may refuse to recognize their marriage to homosexual couples exercising the free movement. Nevertheless, this is not an action against EU rules, as this prohibition applies to all nationals of a given country and there is no discrimination on the basis of origin. Therefore, if the couple entered into a relationship in one Member State, the host state may refuse to legalize this relationship or reduce its status to, for example, a registered relationship (Tryfonidou, 2015: 199202).

From a comparative perspective, the assumption made in the doctrine is important, which states what follows: if a marriage contracted in one of the EU countries is not recognized by other Member States, the principle of the host Member State applies in principle. Failure to recognize the marriage in the host country may result in legal inconvenience, for example in the field of inheritance, tax and social law (Gyeney, 2018: 164-165).

Summarizing the above considerations, it should be emphasized that pursuant to art. $4 \mathrm{sec}$. 2 of the Treaty on European Union, "the Union respects the equality of the Member States before the Treaties as well as their national identity", what is more - the definition of marriage is part of the national identity. It is for these reasons that the 
Court's decision in the above-mentioned case will remain the subject of a doctrinal analysis for a long time to come (Ibidem: 170-171).

\section{RECOGNITION OF SAME-SEX MARRIAGE IN FRANCE}

France was the first country analysed to legalize same-sex marriage. Great Britain did so at a similar time. The doctrine commonly accepts this period as a breakthrough for Europe (Oppenheimer, Oliveira, Blumenthal, 2014: 202-203).

Firstly, from the perspective of the free movement of persons in the EU, it is worth mentioning that France implemented the 2004/38 Directive through 13 legal acts (EUR-Lex, access:13.08.2020). The provisions of the directive are in particular included in Loi $\mathrm{n}^{\circ} 2006-911$ du 24 juillet 2006 relative à l'immigration et à l'intégration.

After the controversial presidency of N. Sarkozy, who believed that equality between homosexual marriages was "humiliating" for simple families, this office was taken over by F. Hollande, whose priority among his socialist reforms was the legalization of same-sex unions. In addition, the French Constitutional Council has declared that same-sex marriage is not contrary to constitutional principles and therefore does not violate fundamental rights, freedoms or national sovereignty in France. The consequence of these actions and positions was the legalization of gay marriage in France in 2013 (Brown, 2016: 236).

Although France has been a secular country for several years, numerous protests have occurred during the process of legalizing homosexual marriage and the influence of the Catholic Church on the politics of this country has increased (Oppenheimer, Oliveira, Blumenthal, 2014: 196).

In France, the legalization of same-sex marriage is included in the legal act: Société: ouverture du mariage aux couples de même sexe (Loi n 2013-404 du 17 mai 2013 ouvrant le mariage aux couples de personnes de même sexe). In addition, France recognizes registered partnerships. The issue was regulated in Loi n ${ }^{\circ}$ 99-944 du 15 novembre 1999 relative au pacte civil de solidarité. Two single-sex adults who are single and plan to live together may enter into a contract before the Pacte Civil de Solidarité Civil Solidarity, if they live together and are not their direct ascendants or descendants.

In conclusion, it should be emphasized that the situation of same-sex marriages in France is clear. France fully recognizes both such marriages and partnerships. Consequently, EU citizens exercising the free movement of persons will be able to fully exercise their right to family reunification in France and their relationship will be recognized in accordance with French internal law.

\section{RECOGNITION OF SAME-SEX MARRIAGE IN IRELAND}

Ireland is on the list of countries that recognize same-sex marriage, but the country legalized it a few years later than France, as described earlier.

It is worth starting legal considerations here with the fact that Ireland implemented 2004/38 Directive on the free movement of persons in the EU into its domestic law by means S.I. No. 548/2015 - European Communities (Free Movement of Persons) Regulations 2015.

The very institution of the family in Ireland is a constitutional value. The country's constitution protects the family in art. 41. First, the article states that the family is "the natural, primordial and fundamental unit of society", while its next point ensures that the state will protect the family as a right provided in the Constitution (Constitution of Ireland, article 41). The text points out that the family is the basis of the social order (Staines, 1976: 223).

Initially, in 2011, Ireland introduced the possibility of registering same-sex relationships. A few years later, in order to introduce regulations on the recognition of homosexual marriages, it was decided to hold a referendum in May 2015. As a result, it was decided to legalize this type of relationship. This decision was positively assessed in the literature due to the changes that took place in the aspect of respecting the law of equality of homosexual couples (Rodgers, 2018: 77-78).

Registration of same-sex partnerships was regulated by the Civil Partnership and Certain Rights and Obligations of Cohabitants Act 2010, however after the referendum and the implementation of the Marriage Act 2015, homosexual couples can no longer register their partnerships. Exceptions were applied to persons who applied for registration by May 15, 2016. Therefore, partnerships registered abroad, including in EU countries, as of May 16, 2016 are not recognized as partnerships in Ireland (Citizens Information, access: 13.08.2020).

Nevertheless, Ireland has allowed homosexual marriage since 2015 . From this year on, same-sex couples can legally marry and have the same rights and obligations as oppositesex couples, while couples who have previously entered into partnerships have the right to marry (Civil Partnership and Certain Rights and Obligations of Cohabitants Act 2010, Number 24 of 2010).

The legalization of same-sex relationships caused the introduction of the $34^{\text {th }}$ Amendment to the Irish Constitution. As a consequence, homosexual couples are protected by the provisions of the Constitution and fall within the scope of the article described above (Ryan, 2015: 20-21). 
Summing up the considerations on same-sex marriage rights, it is worth noting that the literature on the subject talks a lot about the long path that Ireland has gone through in its quest to recognize homosexual unions. Moreover, the doctrine is positive about the decision made in the referendum (Dunne, 2015: 77).

\section{RECOGNITION OF SAME-SEX MARRIAGES IN POLAND}

As it was mentioned at the beginning, the European Union does not harmonize the family law of the Member States, which is why EU countries have the possibility to shape their own legal system in this category. Consequently, this may lead to differences that are of significant importance to families exercising the free movement of persons in the European Union.

As in the case of France and Ireland, Poland implemented 2004/38 Directive - it did so through three legal acts, including in particular the Act on the entry into the territory of the Republic of Poland, residence and departure from this territory of citizens of European Union Member States and members of their families (The Act of 14 July 2006 on the entry into, residence in and exit from the Republic of Poland of nationals of the European Union Member States and their family members, Journal of Laws 2019.293).

However, Poland is the only country among the analysed countries to belong to those European Union Member States which do not recognize any form of same-sex relationships. This means that Polish legal regulations do not allow for the registration of a civil partnership or for same-sex marriage, however, from the point of view of the free movement of workers, it does not violate the principle of nondiscrimination, as the non-recognition of civil partnerships applies to both Polish citizens and foreigners (Wąsik, 2020: 129).

The family, as in the above countries, in Poland is also a value included in the Constitution. Marriage is defined in art. 18 of the Constitution, according to which "marriage as a union of a woman and a man, family, motherhood and parenthood are under the protection and care of the Republic of Poland" (The Constitution of the Republic of Poland., Journal of Laws 1997.78.483, article 18).

The content of the above article has been the subject of an analysis of Polish doctrine for many years due to this controversial provision. According to P. Tulea, the above article may become a source of three potential scenarios related to taking into account the rights of homosexual couples. First, it can be considered that it defines marriage solely as a union between a woman and a man, excluding both homosexual marriage and the institutionalization of civil partnerships. The next scenario assumes the recognition of marriage as a union between a man and a woman and the exclusion of homosexual marriages but allowing the institutionalization of partnerships. The last interpretation assumes, however, that the quoted article prescribes special protection of marriage between men and women, which, however, does not exclude the institutionalization of marriages of same-sex couples, especially partnerships (Tuleja, 2019: 80-83). The doctrine assumes that the second scenario is the most convincing and probable solution, as only the concept of marriage has been specified in the Constitution.

At the end of the deliberations on the content of the Polish Constitution, it is worth noting that the quoted provision does not define the concept of the family in the same way as the Irish Constitution. In addition, art. $31 \mathrm{sec} .1$ and art. 47 of the Constitution guarantees every citizen the right to free development and the possibility to pursue private life (The Constitution of the Republic of Poland., Journal of Laws 1997.78.483, article 31(1) and 47). As a consequence, the above provisions partly oblige to institutionalize in relation to homosexual relationships (Tuleja, 2019: 80-83).

In summary, it is worth noting that the status of samesex couples in the context of Polish law is the subject of numerous scientific publications and still remains a live issue. Polish regulations do not allow any form of legalization of homosexual couples, which affects the principle of the free movement of people in the European Union, as exercising the free movement of persons causes degradation of the marital status of same-sex couples in Polish internal law.

\section{CONCLUSIONS}

At the beginning, it was emphasized that the purpose of this article is to present the issue of the free movement of people in the EU in relation to homosexual couples on the example of Poland, France and Ireland. This problem was presented against the background of EU regulations, CJEU jurisprudence and internal regulations of the analysed countries, with particular emphasis on the provisions of their constitution. Interesting conclusions can be drawn from the considerations.

Firstly, the European Union does not take steps to standardize the issue of marriage and the concept of the family in all Member States. This is a deliberate action that allows respect for the internal regulations of the Member States, but such practice makes it necessary for CJEU to adjudicate in cases concerning the rights of gay relationships and marriages exercising the free movement of persons in the EU. Some of the quoted representatives of the literature on the subject believe that the imprecise regulation of this issue at the $\mathrm{EU}$ level causes numerous case problems. 
Secondly, the free movement of persons is closely related to the EU's right to family reunification, but it could nevertheless be enough to violate this law in Member States that do not recognize same-sex relationships. It is very likely that at some stage the EU will have to take action on this issue and regulate it at EU level. There are concerns that this may breach the limits of respect for the internal values of the European Union states.

Moreover, the countries concerned display significant differences in the recognition of homosexual relationships. France fully recognizes both registered partnerships and same-sex marriage. Ireland does not recognize registered partnerships but does not recognize same-sex marriages. Poland, on the other hand, does not recognize registered partnerships or homosexual marriages. The differences result mainly from internal political and ideological conditions, with a strong religious aspect in Poland. Due to the strong religious influence in Poland, changes in the registration of homosexual relationships will not occur yet, despite the fact that the Polish Constitution does not oppose the registration of gay partnerships.

In connection with the above internal regulations of the analysed countries, it is worth taking a look at certain scenarios concerning the fate of homosexual couples taking advantage of the free movement of people in the European Union. Hypothetically, if a German homosexual couple who remains in a registered partnership decides to make use of the free movement of persons, then: a) their relationship will be fully recognized in France and this does not cause problems under the free movement of persons, b) the partnership of a German couple will not be recognized in Irish law and their status will be degraded, c) the registered partnership of a German couple will not be recognized in Polish law and their marital status will be degraded. Accordingly, in the event of a marriage by a German homosexual couple, their relationship will be fully recognized according to the internal rules in France and Ireland. On the other hand, in Polish law there will be another degradation of the status of marriage, which will not be recognized.

Then, although the European court of human rights is an important institution that protects human rights, the issue of recognizing homosexual relationships and its role and influence over the domestic law of the Member States is not sufficient. On the other hand, the Court of Justice of the European Union, to respect the ideology of the Member States, does not undertake a full interpretation of this issue. The literature may assess such an act in a negative manner. However, the author of the work believes that the attitude of the Court of Justice of the European Union takes into consideration the political and ideological opinions of the member states.
As the article presents, the analysed countries show significant differences in the recognition of homosexual relationships, which affects the recognition of their marital status under the free movement of people. The comparative analysis proves how intrinsically complex the issue of the free movement of persons in the European Union is and how large the impact of this issue is on internal legal areas, such as family law.

In conclusion, it must be stated that the issue of the free movement of persons in the case of homosexual couples is an interesting issue that requires a constant analysis of the doctrine. This topic can be analysed in the context of legal as well as social, economic and political sciences. It is the subject of considerations of the European and international doctrine. Moreover, the comparative element makes it possible to show the differences that exist in the internal regulations of the Member States and to present the analysed issue in various aspects. Undeniably, the topic of the free movement of persons in the European Union in the context of the recognition of same-sex marriages from a comparative perspective has reached the potential, therefore it is important to constantly analyse the internal regulations of the Member States, CJEU rulings and European Union legal regulations.

\section{REFERENCES}

- ACT OF JULY 14, 2006 on the entry into the territory of the Republic of Poland, residence and departure from this territory of citizens of the European Union Member States and their family members. Journal of Laws 2019.293

- BELL, M. (2002). We are Family - Same-Sex Partners and EU Migration Law. Maastricht Journal of European and Comparative Law. 9(4), 335356

- BROWN, J. (2016). Human Rights, Gay Rights, or Both: International Human Rights Law and Same-Sex Marriage, Florida Journal of International Law. 217-240.

- CALDEIRA G.A. \& GIBSON J.L. (1995). The Legitimacy of the Court of Justice in the European Union: Models of Institutional Support. The American Political Science Review. 89(2), 356-376.

- CHARTER OF FUNDAMENTAL RIGHTS OF THE EUROPEAN UNION, Journal of Laws of the EU C.2007.303.1.

- CITIZEN INFORMATION, RIGHTS OF SAME-SEX COUPLES, [online], https://www.citizensinformation.ie/en/birth_family relationships/cohabiting_couples/rights_of_same_sex_couples.html [Access Date: 13/08/2020].

- CITIZENS INFORMATION, CIVIL PARTNERSHIPS, [online], https://www.citizensinformation.ie/en/birth family relationships/civil partnerships/civil_partnership_and_same_sex_couples.html [Access Date: 13/08/2020].

- CIVIL PARTNERSHIP AND CERTAIN RIGHTS AND OBLIGATIONS OF COHABITANTS ACT (2010). Number 24 of 2010.

- CONSTITUTION OF IRELAND

- CONSTITUTION OF THE REPUBLIC OF POLAND OF APRIL 2, 1997, Journal of Laws 1997.78.483. 
- CONVENTION FOR THE PROTECTION OF HUMAN RIGHTS AND FUNDAMENTAL FREEDOMS ROME, 4.XI.1950

- COSTELLO, C. (2009). Metock: free movement and "normal family life" in the Union. Kluwer Law International. 46(2), 587 - 622.

- CUYVERS, A. (2017). Free Movement of Persons in the EU, UGIRASHEBUJA E., RUHANGISA E.J., OTTERVANGER T., CUYVERS A. (ed.), East African Community Law, Brill, Leiden, Boston, ISBN: 978-90-04-32207-3.

- DAVIES, A.C.L., BOGG, A. \& COSTEllo, C. (2016). The role of the Court of Justice in labour law, Bogg A., Costello C., Davies A.C.L., (ed), Research Handbook on EU Labour Law. Cheltenham, Nothampton: Edward Egler Publishing, ISBN: 9781783471119.

- DIRECTIVE 2004/38/EC OF THE EUROPEAN PARLIAMENT AND OF THE COUNCIL OF APRIL 29, 2004 on the right of citizens of the Union and their family members to move and reside freely within the territory of the Member States and amending Regulation (EEC) no. 1612/68 and repealing Directives 64/221/EEC, 68/360/EEC, 72/194/EEC, 73/148/EEC, 75/34/EEC, 75/35/EEC, 90/364/EEC, 90/365/EEC and 93/96/EEC, Journal of Laws of the EU L.2004.158.77.

- DUNNE, P. (2015). Civil Partnership in an Ireland of Equal Marriage Rights. Irish Jurist. 53(1), 77-99.

- EUR-LEX, DIRECTIVE 2004/38/EC OF THE EUROPEAN PARLIAMENT AND OF THE COUNCIL OF 29 APRIL 2004 on the right of citizens of the Union and their family members to move and reside freely within the territory of the Member States amending Regulation (EEC), [online], https://eur-lex.europa.eu/legal-content/EN/ NIM/?uri=CELEX:32004L0038 [Access Date:13/08/2020].

- GUILD, E. (2016). Free Movement of EU Citizens and Their Family Members. New Journal of European Criminal Law. 7(2), 231-249.

- GYENEY, L. (2018). Same Sex Couples' Right to Free Movement in Light of Member States National Identities: The Legal Analysis of The Coman Case, Iustum Aequum Salutare. 14(2), 149-172.

- HAMilton, F. (2018). The case for same-sex marriage before the European Court of Human Rights. Journal of Homosexuality. 65(12), $1582-1606$.

- JACOBI, H.A. (2011) A Furstin by any Other Name - European Citizenship and the Limits of Individual Rights in the E.C.J. Columbia Journal of European Law.17(3), 643-672.

- JUDGEMENT OF THE COURT OF JUNE 5, 2002. Baumbast, C-413/99, EU:C:2002:493.

- JUDGEMENT OF THE COURT OF JUNE 5, 2018. Coman, C-673/16, EU:C:2018:385

- JUDGEMENT OF THE COURT OF OCTOBER 7, 2010. Lassal, C-162/09, EU:C:2010:592.

- JUDGEMENT OF THE COURT OF SEPTEMBER 20, 2001. Grzelczyk, C-184/99, EU:C:2001:458.

- JUOZULYNAS, L. \& ŚMISZEK, K. (2011). The Equal Jus Legal Handbook to LGBT Rights in Europe, Equal Jus, Brussels.

- Loi n 2006-911 du 24 juillet 2006 relative à l'immigration et à l'intégration (1), NOR: INTX0600037L.

- Loi n 2013-404 du 17 mai 2013 ouvrant le mariage aux couples de personnes de même sexe.

- Loi n 99-944 du 15 novembre 1999 relative au pacte civil de solidarité, NOR: JUSX9803236L.

- MACLENNAN, J. \& WARD, A. (2020). The Constitutional Dimension of Case C-673/16 Coman on the Prohibition of Discrimination on the Basis of Sexual Orientation: The Role of Fundamental Rights in Interpreting EU Citizenship. Columbia Journal of European Law. 26(2), 36-62.

- MARRIAGE ACT 2015. Number 35 of 2015.

- Opinion of Advocate General Geelhoed delivered on 5 July 2001, Baumbast, C-413/99, EU:C:2001:385.

- Opinion of Advocate General Tesauro delivered on 14 December 1995, P v S and Cornwall County Council, C-13/94, EU:C:1995:444.
- OPPENHEIMER, B, OLIVEIRA, A. \& BLUMENTHAL, A. (2014). Religiosity and Same-Sex Marriage in the United States and Europe. Berkeley Journal of International Law. 32(1), 195-238.

- RODGERS, G. (2018). Being Gay in Ireland: Resisting Stigma in the Evolving Present. London: Lexington Books, ISBN: 1498555500

- RYAN, F. (2015). Ireland's Marriage Referendum: a Constitutional Perspective. DPCE Online. 2, 1-21.

- S.I. No. 548/2015. European Communities (Free Movement of Persons) Regulations 2015.

- STAINES, M. (1976). The Concept of the Family under the Irish Constitution. Irish Jurist. 11(2), 223-242.

- TREATY ON EUROPEAN UNION, Journal of Laws 2004.90.864/30.

- TREATY ON THE FUNCTIONING OF THE EUROPEAN UNION, Journal of Laws 2004.90.864/2.

- TRYFONIDOU, A. (2015). EU Free Movement Law and the Legal Recognition of Same-Sex Relationships: The Case for Mutual Recognition. Columbia Journal of European Law. 21(2), 195-248.

- TRYFONIDOU, A. (2019). The EU top court rules that married same-sex couples can move freely between EU member states as "spouses": case C-673/16, Relu Adrian Coman, Robert Clabourn Hamilton, Asociaţia Accept v Inspectoratul General pentru Imigrări, Ministerul Afacerilor Interne. Feminist Legal Studies. 27(2), 211-221.

- TULEJA, P. 2019, Art. 18 the principle of protection of marriage and family, [in:] TULEJA P. (ed.), Constitution of the Republic of Poland. Commentary. Warszawa: Wolters Kluwer Polska, ISBN: 978-83-8160970-8.

- VERSCHUEREN, H. (2015). Free Movement of EU Citizens: Including for the Poor. Maastricht Journal of European and Comparative Law. 22(1), 10-34.

- WAALDIJK, K. (1996). Free Movement of Same-Sex Partners. Maastricht Journal of European and Comparative Law. 3(3), 271-286.

- WĄSIK M. 2020, Non-recognition in Poland of Same-Sex Relationships Concluded Abroad - Legal Aspects from The Perspective of The Free Movement of Persons. European Studies - Studies in European Affairs. 24(1), 129-149. 